\title{
The Study on the Development of Strategic Emerging Industry in Shandong Province Based on Factor Analysis
}

\author{
Jian $\mathrm{Xu}^{1, \mathrm{a}}$, Zhenji Jin ${ }^{2, \mathrm{~b}, *}$ \\ ${ }^{1,2}$ Department of Economics and Management \\ Qingdao Agricultural University \\ Qingdao, China \\ axujiansword@163.com, bhenji12@aliyun.com \\ *Corresponding author
}

\begin{abstract}
Since the Eleventh Five-year Plan, Shandong Province has issued a series of policies to promote the development of strategic emerging industries. Developing strategic emerging industries is a path to restructure the economy and transform the economic development pattern. This paper uses the factor analysis and makes an empirical analysis on the strategic emerging industries in Shandong Province. Finally, this paper puts forward the relevant countermeasures for the emerging industries.
\end{abstract}

Keywords-strategic emerging industry; factor analysis; development problem

\section{INTRODUCTION}

The term 'strategic emerging industry' is an innovative vocabulary, which refers to technology-intensive industries that have a leading role in promoting the long-term development of economy and society. Based on major technological breakthrough and development demand, these industries consume less material resources and have a great potential for growth and profitability.

In November 2009, the Premier Wen Jiabao stated that the government builds an innovation-oriented country as a strategic goal, maintains the sustainable development as a strategic direction and obtains the core competitiveness of economy and technology as a strategic priority, which makes strategic emerging industry as the driving force for economic and social development[1].

\section{ANALYSIS OF MAJOR INDUSTRY DEVELOPMENT IN SHANDONG PROVINCE}

Shandong Province, located in the China's eastern areas, is the crucial coastal manufacturing base. In April 2011, the government issued the Decision on Accelerating the Development of Strategic Emerging Industries, specifying 6 emerging industries and 33 main areas of development. The strategic emerging industries consist of new materials, new information technology, energy saving, new medicine and biology, ocean development, high-end equipment manufacturing. The government decides to annually provide the financial supports of no less than 1 billion for the strategic emerging industries. With the effective implementation of various programs and great breakthroughs of innovation, Shandong has made significant progress in some emerging industries.
TABLE I. ECONOMIC INDICATOR OF MAJOR INDUSTRIES IN SHANDONG PROVINCE(2009-2012)

\begin{tabular}{|c|c|c|c|c|c|}
\hline \multirow{2}{*}{ Industry } & \multicolumn{4}{|c|}{ Output Value(Unit:100 million yuan) } & \multirow{2}{*}{$\begin{array}{c}\begin{array}{c}\text { Total Energy } \\
\text { Consumption } \\
\text { (Unit:10000 } \\
\text { ton SCE) }\end{array} \\
2012\end{array}$} \\
\hline & 2009 & 2010 & 2011 & 2012 & \\
\hline $\begin{array}{l}\text { Overall } \\
\text { industry }\end{array}$ & $\begin{array}{l}33896 . \\
65\end{array}$ & $\begin{array}{l}39169 . \\
92\end{array}$ & $\begin{array}{l}45361 . \\
85\end{array}$ & $\begin{array}{c}50013.2 \\
4\end{array}$ & 32229 \\
\hline $\begin{array}{l}\text { Primary } \\
\text { industry }\end{array}$ & $\begin{array}{l}3226.6 \\
4\end{array}$ & $\begin{array}{l}3588.2 \\
8 \\
\end{array}$ & $\begin{array}{l}3973.8 \\
5 \\
\end{array}$ & 4281.70 & 343 \\
\hline $\begin{array}{l}\text { Secondary } \\
\text { industry }\end{array}$ & $\begin{array}{l}18901 . \\
83\end{array}$ & $\begin{array}{l}21238 . \\
49\end{array}$ & $\begin{array}{l}24017 . \\
11\end{array}$ & $\begin{array}{c}25735.7 \\
3 \\
\end{array}$ & 27615 \\
\hline $\begin{array}{l}\text { Tertiary } \\
\text { industry }\end{array}$ & $\begin{array}{l}11768 . \\
18\end{array}$ & $\begin{array}{l}14343 . \\
14\end{array}$ & $\begin{array}{l}17370 . \\
89\end{array}$ & $\begin{array}{c}19995.8 \\
1\end{array}$ & 4271 \\
\hline
\end{tabular}

From Table 1, we can see that in recent years the primary industry, the secondary industry, and the tertiary industry have been developing rapidly, while the GDP is also growing. The output value of secondary industry accounts for the largest proportion of the overall industry.

In terms of energy consumption, in 2012 the secondary industry has a higher rate of energy consumption with a higher output value. The increase of the output value is based on the highly energy wasting. Under such crude and quantitative mode of economic growth, the government will face a series of issues, e.g. resource depletion, environmental damage and economic recession. The government will work hard to transform the economic development pattern, restructure the economy and set out on a path of the balanced and sustainable development[2].

\section{EMPIRICAL RESEARCH ON STRATEGIC EMERGING INDUSTRIES IN SHANDONG PROVINCE}

\section{A. Economic Indicators}

In order to seek the key development areas in Shandong, this paper calculates the related industrial indicators of the emerging dominant industry, makes a deep research using the factor analysis method and points out the relevant strategies. Table 2 shows the definition and description of the economic indicators. 
TABLE II. ECONOMIC INDICATORS AND THEIR DESCRIPTION

\begin{tabular}{|c|c|c|}
\hline $\begin{array}{c}\text { Indicat } \\
\text { or }\end{array}$ & Description & Formula \\
\hline GOV & $\begin{array}{l}\text { Gross industrial output } \\
\text { value }\end{array}$ & (Unit:10000 yuan) \\
\hline IAR & $\begin{array}{l}\text { Investment Absorption } \\
\text { rate }\end{array}$ & $\begin{array}{l}\text { Total investment amount in } \\
\text { one industry to total } \\
\text { investment in the region( } \%)\end{array}$ \\
\hline TA & Total assets & (Unit:10000 yuan) \\
\hline ACR & $\begin{array}{l}\text { Total assets contribution } \\
\text { rate }\end{array}$ & $\begin{array}{l}\text { Sum of total profit, tax and } \\
\text { interests to the average total } \\
\text { assets }(\%)\end{array}$ \\
\hline $\mathrm{TP}$ & Total profits & (Unit:10000 yuan) \\
\hline RTA & Return on total assets & Total profit to total assets( $\%)$ \\
\hline IER & $\begin{array}{l}\text { Employment rate of } \\
\text { investment }\end{array}$ & $\begin{array}{l}\text { The average annual } \\
\text { employment to the average } \\
\text { net value of fixed assets }(\%)\end{array}$ \\
\hline CER & Cost and expense ratios & Total profits to total cost $(\%)$ \\
\hline
\end{tabular}

\section{B. Empirical Analysis}

This paper uses SPSS software and makes the factor analysis of 24 industries in Shandong Province. The calculation results are shown in Table 3.

First, KMO and Bartlett's test is calculated. KaiserMeyer-Olkin measure of sampling adequacy is 0.519, indicating that the sample data are suitable for factor analysis; Bartlett's test of sphericity is 257.970 and reaches the significant level of $1 \%(p=0.000<0.01)$.

Through the principal component analysis, Table 4 shows the total variance explained. The cumulative explained variance of the first three indicators reaches 0.87832 , indicating that the three indicators, whose eigenvalues are all greater than 1 , can represent the whole information of the eight components.

TABLE III. INDUSTRIES AND RELEVANT INDICATORS

\begin{tabular}{|c|c|c|c|c|c|c|c|c|}
\hline Industry & GOV & IAR & TA & ACR & TP & RTA & IER & CER \\
\hline Extraction of petroleum and natural gas & 13241942 & 0.0064 & 16425535 & 0.8062 & 3954124 & 0.2407 & 0.0324 & 0.5691 \\
\hline $\begin{array}{l}\text { Processing of food from agricultural } \\
\text { products }\end{array}$ & 101744055 & 0.0235 & 40974560 & 2.4831 & 6299562 & 0.1537 & 0.0542 & 0.0659 \\
\hline Manufacture of foods & 22144802 & 0.0091 & 12983976 & 1.7055 & 1591653 & 0.1226 & 0.0409 & 0.0789 \\
\hline Manufacture of textile wearing apparel & 19878077 & 0.0071 & 8138787 & 2.4424 & 1246018 & 0.1531 & 0.1138 & 0.0704 \\
\hline Manufacture of furniture & 7196078 & 0.0044 & 3177393 & 2.2648 & 547109 & 0.1722 & 0.0604 & 0.0834 \\
\hline Printing, reproduction of recording media & 4796587 & 0.0038 & 2112529 & 2.2705 & 354310 & 0.1677 & 0.0637 & 0.0812 \\
\hline $\begin{array}{l}\text { Manufacture of articles for culture, arts \& } \\
\text { crafts, sports and entertainment }\end{array}$ & 14589866 & 0.0042 & 5501558 & 2.6520 & 971314 & 0.1766 & 0.0864 & 0.0726 \\
\hline $\begin{array}{l}\text { Manufacture of chemical raw material } \\
\text { chemical products }\end{array}$ & 126492341 & 0.0699 & 73234300 & 1.7272 & 8940431 & 0.1221 & 0.0215 & 0.0749 \\
\hline Manufacture of medicines & 26900133 & 0.0175 & 18124995 & 1.4841 & 2984274 & 0.1646 & 0.0306 & 0.129 \\
\hline Manufacture of rubber and plastic & 46827521 & 0.0200 & 23676542 & 1.9778 & 3234999 & 0.1366 & 0.0330 & 0.0749 \\
\hline $\begin{array}{l}\begin{array}{l}\text { Manufacture of non-metallic mineral } \\
\text { products }\end{array} \\
\end{array}$ & 63103311 & 0.0333 & 35823150 & 1.7615 & 5273991 & 0.1472 & 0.0373 & 0.0934 \\
\hline Manufacture of metal products & 45428526 & 0.0268 & 21506533 & 2.1123 & 3053067 & 0.1420 & 0.0483 & 0.0746 \\
\hline Manufacture of general purpose machinery & 59230183 & 0.0417 & 33603465 & 1.7626 & 4452601 & 0.1325 & 0.0467 & 0.0835 \\
\hline Manufacture of special purpose machinery & 44329274 & 0.0393 & 24927233 & 1.7783 & 3430927 & 0.1376 & 0.1795 & 0.0851 \\
\hline Manufacture of vehicle & 46798355 & 0.0348 & 32849771 & 1.4246 & 2637789 & 0.0803 & 0.1194 & 0.0593 \\
\hline $\begin{array}{l}\text { Manufacture of transport equipment for } \\
\text { railway, shipping, aerospace and other } \\
\text { uses }\end{array}$ & 14811106 & 0.0147 & 13765468 & 1.0760 & 914078 & 0.0664 & 0.0852 & 0.0696 \\
\hline $\begin{array}{l}\text { Manufacture of electrical machinery \& } \\
\text { equipment }\end{array}$ & 53679478 & 0.0312 & 30448803 & 1.7630 & 3494771 & 0.1148 & 0.0441 & 0.0702 \\
\hline $\begin{array}{l}\text { Manufacture of computer, communication } \\
\text { equipment and other electronic equipment }\end{array}$ & 40026972 & 0.0151 & 17556846 & 2.2798 & 2115692 & 0.1205 & 0.0689 & 0.0555 \\
\hline Manufacture of measuring instrument & 5650269 & 0.0048 & 2883990 & 1.9592 & 464034 & 0.1609 & 0.0726 & 0.0946 \\
\hline $\begin{array}{l}\text { Processing of timbers, manufacture of } \\
\text { wood, bamboo, rattrap, palm, and straw } \\
\text { products }\end{array}$ & 16539333 & 0.0068 & 4636249 & 3.5674 & 1202326 & 0.2593 & 0.0798 & 0.0801 \\
\hline Manufacture of chemical fiber & 2106016 & 0.0012 & 1826273 & 1.1532 & 152031 & 0.0832 & 0.0277 & 0.0799 \\
\hline Recycling and disposal of waste resource & 656974 & 0.0015 & 236926 & 2.7729 & 61385 & 0.2591 & 0.0551 & 0.104 \\
\hline Production and supply of gas & 1891047 & 0.0028 & 2460008 & 0.7687 & 191995 & 0.0780 & 0.0142 & 0.0997 \\
\hline Manufacture of paper and paper products & 24581087 & 0.0114 & 21209592 & 1.1590 & 1484771 & 0.0700 & 0.0203 & 0.0638 \\
\hline
\end{tabular}


TABLE IV. TOTAL VARIANCE EXPLAINED

\begin{tabular}{|l|l|l|l|l|l|l|}
\hline \multirow{2}{*}{$\begin{array}{c}\text { Com } \\
\text { pone } \\
\text { nt }\end{array}$} & \multicolumn{3}{|c|}{ Initial Eigenvalues } & \multicolumn{3}{c|}{$\begin{array}{c}\text { Extraction Sums of Squared } \\
\text { Loadings }\end{array}$} \\
\cline { 2 - 7 } & Total & $\begin{array}{c}\text { \% of } \\
\text { variance }\end{array}$ & $\begin{array}{c}\text { Cumul } \\
\text { ative \% }\end{array}$ & Total & $\begin{array}{c}\text { \% of } \\
\text { variance }\end{array}$ & $\begin{array}{c}\text { Cumula } \\
\text { tive \% }\end{array}$ \\
\hline 1 & $\begin{array}{l}3.86 \\
3\end{array}$ & 48.286 & 48.286 & $\begin{array}{l}3.86 \\
3\end{array}$ & 48.286 & 48.286 \\
\hline 2 & $\begin{array}{l}1.68 \\
4\end{array}$ & 21.054 & 69.341 & $\begin{array}{l}1.68 \\
4\end{array}$ & 21.054 & 69.341 \\
\hline 3 & $\begin{array}{l}1.47 \\
9\end{array}$ & 18.491 & 87.832 & $\begin{array}{l}1.47 \\
9\end{array}$ & 18.491 & 87.832 \\
\hline
\end{tabular}

Through the orthogonal rotation, Table 5 shows the rotated component matrix and Table 6 shows the component score coefficient matrix. The total variance of the first three indicators reaches $87.832 \%$. Each main indicator equation is as follows.

$\mathrm{F} 1=0.265 * \mathrm{GOV}+0.245 * \mathrm{IAR}+0.258 * \mathrm{TA}+0.049 * \mathrm{ACR}+$

$0.271 * \mathrm{TP}+0.033 * \mathrm{RTA}-0.003 * \mathrm{IER}+0.006 * \mathrm{CER}$

$\mathrm{F} 2=0.042 * \mathrm{GOV}-0.037 * \mathrm{IAR}-0.017 * \mathrm{TA}+0.416 * \mathrm{ACR}+$

$0.122 * \mathrm{TP}+0.594 * \mathrm{RTA}+0.079 * \mathrm{IER}+0.256 * \mathrm{CER}$

$\mathrm{F} 3=0.056 * \mathrm{GOV}+0.073 * \mathrm{IAR}-0.029 * \mathrm{TA}+0.368 * \mathrm{ACR}-$ $0.121 * \mathrm{TP}-0.116 * \mathrm{RTA}+0.393 * \mathrm{IER}-0.558 * \mathrm{CER}$

TABLE V. ROTATED COMPONENT MATRIX

\begin{tabular}{|l|c|c|l|}
\hline \multirow{2}{*}{} & \multicolumn{3}{|c|}{ Component } \\
\cline { 2 - 4 } TA & $\mathbf{1}$ & \multicolumn{1}{c|}{$\mathbf{3}$} & \multicolumn{1}{|c|}{} \\
\hline GOV & 0.982 & -0.146 & -0.058 \\
\hline TP & 0.979 & -0.040 & 0.083 \\
\hline IAR & 0.972 & 0.071 & -0.188 \\
\hline RTA & -0.134 & -0.162 & 0.101 \\
\hline ACR & -0.016 & 0.720 & -0.117 \\
\hline CER & -0.070 & 0.367 & -0.848 \\
\hline IER & -0.063 & 0.178 & 0.627 \\
\hline
\end{tabular}

From the above analysis, we can get the industry comprehensive assessment function.

$$
\Sigma \mathrm{W}_{\mathrm{i}} \mathrm{F}_{\mathrm{i}}=0.48286 * \mathrm{~F} 1+0.21054 * \mathrm{~F} 2+0.18491 * \mathrm{~F} 3
$$

The values of each indicator are put into Eq. (4) through standardization. Table 7 shows the comprehensive evaluation results of each industry according to the comprehensive score.
TABLE VI. COMPONENT SCORE COEFFICIENT MATRIX

\begin{tabular}{|l|l|l|l|}
\hline \multirow{2}{*}{} & \multicolumn{3}{|c|}{ Component } \\
\cline { 2 - 4 } GOV & $\mathbf{1}$ & \multicolumn{1}{|c|}{$\mathbf{2}$} & \multicolumn{1}{|c|}{} \\
\hline IAR & 0.265 & 0.042 & 0.056 \\
\hline TA & 0.258 & -0.037 & 0.073 \\
\hline ACR & 0.049 & -0.017 & -0.029 \\
\hline TP & 0.271 & 0.122 & -0.121 \\
\hline RTA & 0.033 & 0.594 & -0.116 \\
\hline IER & -0.003 & 0.079 & 0.393 \\
\hline CER & 0.006 & 0.256 & -0.558 \\
\hline
\end{tabular}

TABLE VII. RESULTS OF FACTOR ANALYSIS

\begin{tabular}{|c|c|c|c|c|c|}
\hline $\begin{array}{l}\text { Ran } \\
\text { king }\end{array}$ & Industry & F1 & F2 & F3 & $\begin{array}{c}\text { Compre } \\
\text { hensive } \\
\text { score } \\
\end{array}$ \\
\hline 1 & $\begin{array}{l}\text { Manufacture of } \\
\text { chemical raw } \\
\text { material chemical } \\
\text { products }\end{array}$ & 3.1342 & $\begin{array}{l}- \\
0.1730\end{array}$ & $\begin{array}{l}- \\
0.3591\end{array}$ & 1.4106 \\
\hline 2 & $\begin{array}{l}\text { Processing of food } \\
\text { from agricultural } \\
\text { products }\end{array}$ & 1.5115 & 0.6542 & 0.3428 & 0.9310 \\
\hline 3 & $\begin{array}{l}\text { Manufacture of } \\
\text { special purpose } \\
\text { machinery }\end{array}$ & 0.5908 & 0.0878 & 1.3367 & 0.5510 \\
\hline 4 & $\begin{array}{l}\text { Manufacture of } \\
\text { non-metallic } \\
\text { mineral products }\end{array}$ & 1.0716 & 0.0370 & $\begin{array}{l}- \\
0.3349\end{array}$ & 0.4633 \\
\hline 5 & $\begin{array}{l}\text { Processing of } \\
\text { timbers, } \\
\text { manufacture of } \\
\text { wood, bamboo, } \\
\text { rattrap, palm, and } \\
\text { straw products }\end{array}$ & 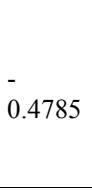 & 2.2804 & 1.0292 & 0.4394 \\
\hline
\end{tabular}

From the score analysis of the first factor, manufacture of chemical raw material chemical products is ranked No.1, followed by processing of food from agricultural products and manufacture of non-metallic mineral products. These pillar industries make great contribution to the economy. However, from the score analysis of the second factor, the scores are relatively low, indicating that the investment cannot promote the application of technological achievements.

From the score analysis of the second factor, the top three industries are processing of timbers, manufacture of wood, bamboo, rattrap, palm, and straw products, recycling and disposal of waste resource and extraction of petroleum and natural gas. The investments of these three industries are lower, while the gross output values are larger. To a certain extent, these industries can alleviate the pressure of employment. However, these industries should improve the production efficiency and introduce the talents. 
From the score analysis of the third factor, manufacture of special purpose machinery and manufacture of textile wearing apparel have some advantages, indicating that the government intends to increase the R\&D investment and improve the productivity.

In conclusion, based on the above analysis, the government should develop manufacture of chemical raw material chemical products, processing of food from agricultural products and manufacture of special purpose machinery. Thus, the government pays attention to other emerging industries, e.g. biological medicine, biological energy, marine, high-end equipment and new energy vehicles.

\section{POLICY IMPLICATION}

\section{A. Promote the Differentiation of the Leading Industries}

With respect to the planning of strategic emerging industries in Shandong, compared with other provinces, the government generally expands the scope of emerging industries. Contrary to the relevant regulations, some traditional high-tech industries and the leading industries are included in the scope of strategic emerging industries. At the provincial level, the government should allocate resources rationally and improve industrial concentration according to the actual local conditions[3]. For the cities, the local government should promote the development of the industries with new technology and the core competitiveness, based on the long-term sustainable development in the region.

\section{B. Encourage Innovation of Strategic Emerging Industries}

Enterprises should encourage the basic and applied researches. To provide technical supports, the scientific researches and technological applications are carried out in the specific industries, e.g. marine biotechnology, marine equipment manufacturing, air power technology, high-end ship manufacturing, biomedical technology and high-end computer manufacturing.

Enterprises intend to encourage the continuous innovation. Enterprises make efforts to avoid excessive scale expansion, set up the technological innovation mechanism and enhance the innovation performance. Governments attempt to increase the scientific investments, establish supporting measures to encourage the technology innovation and enhance the capability of corporate independent innovation[4].

\section{Increase the Fiscal and Financial Supports}

\section{1) Increase financial input}

The government tends to gradually increase the special funds for strategic emerging industries in the financial budgets, set up advanced platforms engaged in the product research and development, encourage technological progress and innovation and provide technical supports for the major transformation projects. Blue Economic Zone in Shandong makes more investments in technology research and development, industrialization and innovation of strategic emerging industries[5].

2) Enhance the leverage of tax

Tax policy is an important tool for the government to support strategic emerging industries. Government should conscientiously implement a series of tax policies for new technology and product and provide tax incentives for emerging enterprises.

\section{REFERENCES}

[1] Wei Jiabao, Science and Technology leading China's Sustainable Development, China, 2009.

[2] Shen Mengkang, "Empirical Research on Regional Strategic Emerging Industry Choice Based on Factor Analysis", Enterprise Economy, China, vol. 9, pp. 106-109, 2012.

[3] Fu Guangjun, "Enhance Development of Strategic New Industries by Tax Policies", Journal of Lanzhou Commercial College, China, vol. 2, pp. 1-9, 2011.

[4] Jiang Zhen and Liang Jun, "Tax Policies to Promote the Development of Strategic Emerging Industries", Taxation Research, China, vol. 8, pp. 8-12, 2010.

[5] Wu Ruijie, "Evaluation and Selection of Regional Strategic Emerging Industry", Scientific Management Research, China, vol. 2, pp. 42-45, 2012. 
